\title{
MRS Letter Calls for Increase in DoD Funding for FY 2000
}

In correlation with a statement sent out at the end of April by the Coalition for National Security Research (CNSR) endorsing a recommendation from the U.S. Department of Defense (DoD) to increase funding for its Science and Technology Program (see Washington News, this issue), Materials Research Society President Ronald Gibala of the University of Michigan sent a letter to DoD reiterating the call. The MRS letter was sent to members of the Senate and House Armed Services Committees and House and Senate Appropriators who work with DoD. See sidebar for the text of the letter.

\section{Provious Public Alfairs} Forum articles

- SSSC Forum Delineates Future Role of Materials Research in U.S. Scientific Policy, Thomas P. Russell and Julia M. Phillips, MRS Bulletin, Vol. 24, No. 5, May 1999

- An Alchemy of Diciplines, Rita Colwell, MRS Bulletin, Vol. 24, No. 4, April 1999

- Spallation Neutron Source to Provide Facilities to Conduct World-Class Science, Thomas A. Weber, MRS Bulletin, Vol. 24, No. 2, February 1999

- New Era of Science Policy Addresses Future Challenges, Vernon J. Ehlers, MRS Bulletin, Vol. 23, No. 11, November 1998

- MRS Goes to Washington, Robert J. Nemanich, MRS Bulletin, Vol. 23, No. 9 , September 1998

- FMS Meeting Addresses Materials R\&D Role in the U.S. Scientific Innovation Process, Merton C. Flemings, MRS Bulletin, Vol. 23, No. 8, August 1998

- CMMP Report lllustrates Impact of Materiais Physics on Society, MRS Bulletin, Vol. 23, No. 2, February 1998

- Materials Science and Nonproliferation: Scientists Influence National Policy, Michal Freedhoff, MRS Bulletin, Vol. 23, №. 1, January 1998

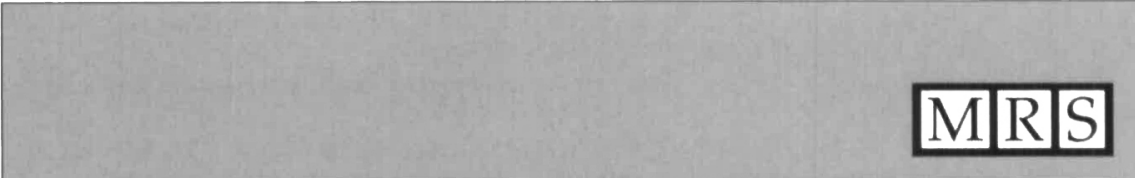

As the president of the 12,000 member Materials Research Society, I am writing with concern about the continuing decline in funding for national security-related research in all areas of science and engineering. This concern is reinforced by the conclusions of the Defense Science Board Task Force on Defense Science and Technology Base for the 21st Century. Their report strongly recommends a significant increase in the Department of Defense Science and Technology Program in the FY 2000 request.

The marked reductions in defense-oriented research over the past several years, including the significant loss of support to universities, industry, and the DoD labs themselves, cannot help but to adversely affect our ability to meet our defense obligations in the coming decades. The DoD science and technology programs support research at universities that both creates needed fundamental discoveries and applies science to future military technology. This support also plays a critical role in sustaining disciplines where it is a major source of federal funding, driving innovation, and training future engineers and scientists.

The DoD science and technology programs also fund research at defense laboratories and private industry that focuses on technologies to support future DoD systems. Such research enables the longer term, revolutionary advances in military technology that will keep our U.S. forces significantly dominant in any situation and enable quick response to the emerging threats of chemical, nuclear, and biological agents from terrorist groups and rogue nations.

The level of support suggested by the Defense Science Board Task Force is of the order required to maintain the level of research that has allowed U.S. forces to control any hostile situation. It is only through a continued commitment to defense-related science and technology programs that we can maintain our technological superiority. I urge you to support the increased level of funding needed for maintaining the research and development effort necessary to ensure national security.

Sincerely yours,

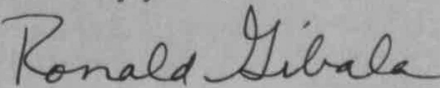

Ronald Gibala

1999 President

Materials Research Society 


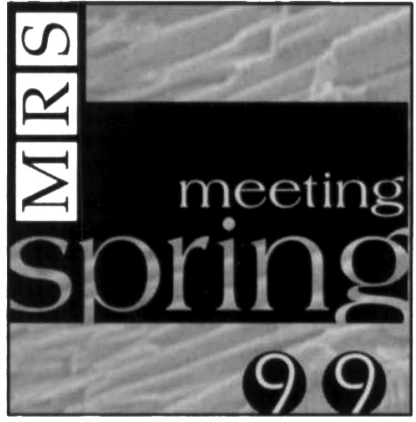

\section{Spring Meeting Symposium Proceedings} Place your order today for proceedings of the visit our Web site at:
1999 MRS Spring Meeting in San Francisco!
www.mprs.org/publications/boots/

These books are scheduled for publication by early fall or winter 1999 .

A: Amorphous and Heterogeneous Silicon Thin Films: Fundamentals to Devices-1999

Editors: H.M. Branz, R.W. Collins, H. Okamoto, S. Guha, R. Schropp

ISBN: 1-55899-464-5 Code: 557-B $\begin{array}{ll}\$ 65.00 & \text { MRS Member } \\ \$ 77.00 & \text { U.S. List }\end{array}$

$\$ 85.00$ Non-U.S.

B: Flar-Panel Displays and SensorsPrinciples, Materials and Processes Editors: F.R. Libsch, B. Chalamala, R. Friend, T. Jackson, H. Ohshima

ISBN: 1-55899-465-3

$\begin{array}{ll}\$ 62.00 & \text { MRS Member } \\ \$ 73.00 & \text { U.S. List }\end{array}$
Code: $558-\mathrm{B}$

$\$ 80.00$ Non-U.S.

D: Liquid Crystal Materials and Devices Editors: T.J. Bunning, S.H. Chen, L.C. Chien,

S-C.A. Lien, T. Kaijyama, N. Koide

ISBN: 1-55899-466-1 Code: 559-B $\$ 58.00$ MRS Member

$\$ 68.00$ U.S. List

$\$ 75.00$ Non-U.S.

E: Luminescent Materials

Editors: J. McKittrick, A. Kitai, K. Mishra, C. Ronda, B. DiBartolo

ISBN: $1-55899-467-X$ Code: $560-B$

$\$ 62.00$ MRS Member

$\$ 80.00$ Non-U.S.

F: Organic Nonlinear Optical Materials and Devices

Editors: B. Kippelen, H. Lackritz, R. Claus

ISBN: 1-55899-468-8 Code: 561-B

$\$ 61.00$ MRS Member

$\$ 72.00$ U.S. List

$\$ 79.00$ Non-U.S.

L: Polycrystalline Metal and Magnetic Thin Films

Editors: K.P. Rodbell, D. Laughlin, O. Thomas,

B. Zhang

ISBN: 1-55899-469-6 Code: 562-B

$\$ 59.00$ MRS Member

$\$ 69.00$ U.S. List

$\$ 76.00$ Non-U.S.

M: Materials Reliability in Microelectronics IX

Editors: C.A. Volkert, A.H. Verbruggen, D. Brown

ISBN: 1-55899-470-X

$\begin{array}{ll}\$ 61.00 & \text { MRS Member } \\ \$ 72.00 & \text { U.S. List }\end{array}$

$\$ 72.00$ U.S. List

$\$ 79.00$ Non-U.S.

N: Advanced Interconnects and Contacts

Editors: D.C. Edelstein, T. Kikkawa, M. Ozturk,

K-N. Tu, E. Weitzman

ISBN: 1-55899-471-8

$\begin{array}{ll}\$ 62.00 & \text { MRS Member } \\ \$ 73.00 & \text { U.S. List } \\ \$ 80.00 & \text { Non-U.S. }\end{array}$

Code: $564-B$

$\$ 80.00$
O: Low-Dielectric Constant Materials V

Editors: J.P. Hummel, K. Endo, W.W. Lee, M.E. Mills,

S.Q. Wang

ISBN: 1-55899-472-6 Code: $565-B$

$\$ 60.00$ MRS Member

$\$ 70.00 \quad$ U.S. List

$\$ 77.00 \quad$ Non-U.S.

P: Chemical-Mechanical PolishingFundamentals and Challenges

Editors: S.V. Babu, S. Danyluk, M.I. Krishnan,

$M$. Tsujimura

ISBN: 1-55899-473-4 Code: $566-\mathrm{B}$

$\$ 60.00$ MRS Member

$\$ 70.00$ U.S. List

$\$ 77.00 \quad$ Non-U.S.

R: Ultrathin $\mathrm{SiO}_{2}$ and High-K Materials for ULSI Gate Dielectrics

Editors: H.R. Huff, M.L. Green, T. Hattori, G. Lucovsky,

C.A. Richter

ISBN: 1-55899-474-2 Code: 567-B

$\$ 64.00$ MRS Member

$\$ 75.00$ U.S. List

$\$ 82.00 \quad$ Non-U.S.

S: Silicon Front-End Processing-

Physics and Technology of

Dopant-Defect Inferactions

Editors: H.J.L. Gossmann, T.E. Haynes, M.E. Law,

A.N. Larsen, S. Odanaka

ISBN: 1-55899-475-0 Code: 568-B

$\$ 60.00$ MRS Member

$\$ 70.00 \quad$ U.S. List

$\$ 77.00 \quad$ Non-U.S.

U: In Situ Process Diagnostics and Modelling Editors: O. Auciello, A.R. Krouss, E.A. Irene,

J.A. Schultz

ISBN: 1-55899-476-9 Code: 569-B

$\$ 60.00$ MRS Member

$\$ 70.00$ U.S. List

$\$ 77.00 \quad$ Non-U.S

V: Epitaxial Growth

Editors: T.P. Pearsall, A-L. Barabasi, F. Lu,

G.N. Maracas

ISBN: 1-55899-477-7 Code: 570-B

$\$ 62.00$ MRS Member

$\$ 73.00$ U.S. List

$\$ 80.00$ Non-U.S.

W: Semiconductor Quantum Dots

Editors: D. Ila, H. Lee, S. Moss, D. Norris

ISBN: 1-55899-478-5 Code: 571-B

$\$ 63.00 \quad$ MRS Member

$\$ 74.00$ U.S. list

$\$ 81.00 \quad$ Non-U.S
Y: Wide-Bandgap Semiconductors for High-Power, High-Frequency and High-Temperature Applications-1999

Editors: S. Binari, A. Burk, M. Melloch, C. Nguyen

ISBN: 1-55899-479-3

Code: $572-\mathrm{B}$

$\$ 63.00$ MRS Member

$\$ 74.00$ U.S. List

$\$ 81.00$ Non-U.S.

Z: Compound Semiconductor Surface Passivation and Novel Device Processing Editors: H. Hasegowa, M. Hong, Z.H. Lu, S.J. Pearton ISBN: 1-55899-480-7 Code: 573-B
$\$ 60.00 \quad$ MRS Member
$\$ 70.00$ U.S. List
$\$ 77.00$ Non-U.S

BB: Multicomponent Oxide Films for Electronics

Editors: M.E. Howley, D.H. Blank, C-B. Eom,

S.K. Streiffer, D.G. Schlom

ISBN: 1-55899-481-5

$\$ 64.00$ MRS Member

$\$ 75.00 \quad$ U.S. list

$\$ 82.00$ Non-U.S

CC: New Materials for Batteries and Fuel Cells Editors: D.H. Doughty, H-P. Brack, K. Naoi, L.F. Nazar ISBN: 1-55899-482-3
$\$ 62.00$
MRS Member
$\$ 73.00$
U.S. List
$\$ 80.00$
Non-U.S.

DD: Organic/Inorganic Hybrid Materials II

Editors: L.C. Klein, L. Francis, M.R. DeGuire,

J.E. Mark

ISBN: 1-55899-483-1 Code: 576-B

$\$ 63.00$ MRS Member

$\$ 74.00$ U.S. List

$\$ 81.00$ Non-U.S

H/l: Advanced Hard and Soft Magnetic Materials

Editors: L.H. Lewis, J.M.D. Coey, B-M. Ma, T. Schreff,

L. Schultz, M.E. McHenry, V.G. Harris, J. Fidler,

R. Hasegawa, A. Inove

ISBN: 1-55899-485-8
$\$ 72.00$
MRS Member
$\$ 80.00$ U.S. List
$\$ 89.00 \quad$ Non-U.S

Code: $577-B$

$\$ 89.00 \quad$ Non-U.S

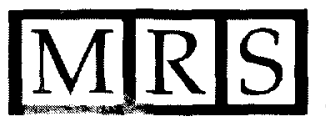

Materials

Research

Society

506 Keystone Drive, Worrendale, PA 15086-7573 U.S.A.

Tel: 724-779-3003 - Fax: 724-779-8313

E-mail: info@mrs.org • umw.mrs.org/publications/books/ 